\title{
Evaluation of the Effectiveness of Tenofovir in Chronic Hepatitis B Patients
}

\author{
Seval Müzeyyen Ecin ${ }^{1, *}$, [MD] \\ ORCID:0000-0002-7701-7826 \\ Nursel Çalık Başaran², [MD] \\ ORCID:0000-0002-1290-6905 \\ Murat Aladağ $\breve{g}^{3},[\mathrm{MD}]$ \\ ORCID:0000-0002-4563-7027
}

\section{we) ABSTRACT Cen}

Objectives: HBV infection is a global public health problem. Tenofovir disoproxil fumarate and tenofovir alafenamide are nucleotide reverse transcriptase inhibitors and used for the treatment of chronic Hepatitis B infection. The aim of this study was to evaluate treatment response and efficacy of Tenofovir disoproxil fumarate. Materials and Methods: The study included hepatitis B positive patients who started to use Tenofovir disoproxil fumarate. We retrospectively reviewed electronic medical files of Hepatitis B patients. Hepatitis B surface antigen, Hepatitis B surface antibody, Hepatitis B e antigens, Hepatitis B e antibody, Hepatitis B viral DNA, aspartate aminotransferase, alanine aminotransferase values were evaluated in the $1^{\text {st }}, 3^{\text {rd }}, 6^{\text {th }}$, $9^{\text {th }}$, and $12^{\text {th }}$ months.

Result: None of the patients under Tenofovir disoproxil fumarate treatment was "primary resistant". Alanine aminotransferase normalization at $12^{\text {th }}$ month was seen in $80.4 \%$ of study population. Hepatitis B surface antigen seroconversion was detected only in one patient $(0.85 \%)$ at $9^{\text {th }}$ months and Hepatitis B e antigen seroconversion was observed in 9 patients (8.3\%) under Tenofovir disoproxil fumarate treatment. At the sixth month of Tenofovir disoproxil fumarate treatment, complete response was found in 77 (65.8\%), partial response in 21 (18\%) and inadequate response were in 19 (16.2\%). Among Hepatitis B e antigen positive patients, 44 (80 \%) patients had undetectable Hepatitis B virus DNA levels at the end of $12^{\text {th }}$ month and among Hepatitis B e antigens negative patients, 52 (91.2\%) patients had undetectable Hepatitis B DNA levels at the end of $12^{\text {th }}$ month $(\mathrm{p}<0.01)$.

Conclusion: Among patients with chronic HBV infection, Tenofovir disoproxil fumarate had satisfying antiviral efficacy. There is no primary resistance in patients treated with Tenofovir disoproxil fumarate. Patients had statistically significant improvement in aspartate aminotransferase, alanine aminotransferase, Hepatit B virus DNA levels.

Key words: Chronic Hepatitis B, tenofovir, treatment

\section{INTRODUCTION}

Hepatitis B virus (HBV) is a double-stranded DNA virus, family of hepadna viruses. HBV infection is a global public health problem. It is estimated that there are more than 250 million HBV infected patients in the world, of whom approximately 600,000 die annually from HBV-related liver disease [1]. Chronic hepatitis B (CHB) is endemic at sub-Saharan Africa and the Asia/Pacific where the infection transmitted through perinatally or horizontally during early childhood. In Western countries, HBV spreads through high risk sexual behavior, injection drug use and exposure to blood product $[2,3]$. The likelihood of liver failure from acute HBV is less than 1 percent, and in immunocompetent adults, the likelihood of progression to chronic HBV infection is less than 5 percent [4]. Diagnosis of CHB 
is based upon the persistence of hepatitis B surface antigen ( $\mathrm{HBsAg}$ ) for at least six months [5]. Serum HBV DNA levels are important predicting the development of cirrhosis and hepatocellular carcinoma (HCC) [6]. The overall goal of treatment for $\mathrm{CHB}$ is to prevent or reduce the development of cirrhosis, end-stage liver disease, HCC and death. Short-term goals of the treatment are viral suppression, normalization of ALT, absence of viral resistance, hepatitis $B$ e antigen ( $\mathrm{HBeAg}$ ) loss, and seroconversion, hepatitis B surface antigen ( $\mathrm{HBsAg}$ ) loss, and seroconversion, and improvement in liver histology [7]. $\mathrm{CHB}$ treatment are currently based on $\mathrm{HBeAg}$ status, HBV DNA levels and ALT levels. Patients with $\mathrm{CHB}$ are initially classified as having either $\mathrm{HBeAg}$ positive or HBeAg-negative. There are seven agents currently available for the treatment: interferon al$\mathrm{fa}-2 \mathrm{~b}$, peginterferon alfa-2a, lamivudine, entecavir, telbivudine, adefovir, tenofovir [7].

Tenofovir disoproxil fumarate (TDF) and tenofovir alafenamide (TAF) are nucleotide reverse transcriptase inhibitors (NRTIs) that are used for the treatment of CHB infection. TDF is an acyclic nucleotide diester analog of adenosine monophosphate, which is administered orally as the prodrug TDF (300 mg daily) or TAF (25 mg daily). TDF can be used as first-line therapy in treatment or in those who have had prior exposure, or developed drug resistance, to other nucleos(t)ide analogues [8].

The aim of this study was to evaluate the treatment response and efficacy of TDF, which was a new treatment regimen in Turkey at that time period.

\section{MATERIALS and METHODS}

This descriptive, retrospective study was conducted between January 2009 and January 2011 at Inonu University Faculty, Turgut Ozal Medicine Center, Department of Internal Medicine, Division of Hepatology Outpatient Clinic. We included hepatitis B positive patients who used TDF. Treatment naïve as well as treatment experienced patients were included in this study. We retrospectively reviewed the electronic medical files of $\mathrm{CHB}$ patients. HBsAg, Hepatit B surface antibody (Anti-HBsAb),
HBeAg, Hepatit B e antibody (Anti-HBeAb), HBVDNA $, 1^{\text {st }}, 3^{\text {rd }}, 6^{\text {th }}, 9^{\text {th }}$ and $12^{\text {th }}$ aspartate aminotransferase (AST), alanine aminotransferase (ALT) values were evaluated in the 1, 3., 6., 9., and 12. months. The patients with decompensated cirrhosis, liver disease due to another cause, HIV infection, previous organ transplantation, decompensated cardiovascular disease, uncontrolled psychiatric or convulsive diseases, uncontrolled hemoglobinopathies and hemophilia, autoimmune disease, abnormal serum creatinine values, cytopenia (hemoglobin< $12 \mathrm{~g} / \mathrm{dl}$, leukocyte count $<3500 / \mathrm{mm} 3$, neutrophil count $<1500$ / mm3, platelet count $<100000 / \mathrm{mm} 3$ ), positive autoantibodies ( antinuclear antibodies (ANA), antimitochondrial antibodies (AMA), Anti-smooth muscle antibodies (ASMA), Anti-liver-kidney microsomal-1 (ALKM-1)) were excluded from the study.

$3^{\text {rd }}$ and $6^{\text {th }}$ month Evaluation of Treatment Results Indicators of the effectiveness of treatment are suppression of HBV DNA and loss of hepatitis $B$ e antigen $(\mathrm{HBeAg}$ ) (in patients who were initially $\mathrm{HBeAg}$ positive) and followed by loss of hepatitis $B$ surface antigen ( $\mathrm{HBsAg}$ ) Virologic response can be classified as complete, partial, or inadequate according to viral DNA change at the end of 24 weeks of therapy. Complete virologic response was defined as HBV DNA levels $<60 \mathrm{IU} / \mathrm{ml}$ ( $<300$ copies/ml), which is the lower limit of detection of standard PCR assays, while a partial virologic response was defined as residual HBV DNA levels less than $2,000 \mathrm{IU} / \mathrm{ml}(<4$ $\log 10$ copies $/ \mathrm{ml}$ ) at week 24 . Inadequate virologic responses were defined as residual HBV DNA levels of $\geq 2,000 \mathrm{IU} / \mathrm{ml}$ ( $\geq 4 \log 10$ copies $/ \mathrm{ml}$ ) at week 24 [9]. Primary resistance was accepted if serum HBV DNA concentration was not reduced by at least $1 \log 10$ in the end of 3 months of treatment. HBV DNA was studied with Rotor-Gene 6000 Real-Time PCR and Arthus HBVRG-DNA kit.

Rights and privacy of patients were protected. Ethical approval is not available, as this study is a retrospective study completed in 2011. The study was carried out in accordance with the Declaration of Helsinki and its amendments.

Statistical analysis

Data were analyzed using IBM SPSS Statistics for 
Windows, version 21.0 (IBM Corp., Armonk, NY, USA). Descriptive statistics of continuous variables with normal distributions were given as means \pm standard deviation whereas those without normal distributions were given as median and minimum-maximum range. Wilcoxon signed-rank test and $\mathrm{Mc}$ Nemar's test were used to compare two or more dependent variables. P-values below 0.05 were considered statistically significant.

\section{RESULTS}

We included $117 \mathrm{HBV}$ - positive patients using TDF between 2009-2011 years. The mean age was $42.0 \pm$

Table 1. Distribution of AST, ALT, HBV DNA values 1st, 3rd, 6th, 9th and 12th month

\begin{tabular}{|l|c|c|c|}
\hline \multicolumn{1}{|l|}{} & $\begin{array}{c}\text { AST units/L } \\
\text { (median (min-max) }\end{array}$ & ALT units/L (median (min-max)) & HBV DNA IU/ml (median (min-max)) \\
$1^{\text {st }}$ month & $36(15-873)$ & $46(13-796)$ & $124 \times 103(0-12 \times 109)$ \\
$3^{\text {rd }}$ month & $28(15-511)$ & $35(12-249)$ & $1544(0-34000747)$ \\
$6^{\text {th }}$ month & $28(14-386)$ & $33(11-377)$ & $41.5(0-9 \times 106)$ \\
$9^{\text {th }}$ month & $25(10-147)$ & $27(9-134)$ & $0(0-3 \times 106)$ \\
$12^{\text {th }}$ month & $25(14-105)$ & $22(11-129)$ & $0(0-2000387)$ \\
$P^{*}$ values & $<0.05$ & $<0.05$ & $<0.05$ \\
\hline
\end{tabular}

* Decline values of AST, ALT, HBV DNA from 1. to 12. months were compared by using Wilcoxon signed-rank test

HBV DNA levels of HBeAg positive and HBeAg negative patients are given Table 2.

Table 1. Distribution of AST, ALT, HBV DNA values 1st, 3rd, 6th, 9th and 12th month

\begin{tabular}{|l|c|c|}
\hline \multicolumn{2}{|c|}{ HBV DNA IU/ml (median (min-max)) } \\
\hline \multicolumn{1}{|l|}{$1^{\text {st }}$ month } & HBeAg Positive & HBeAg Negative \\
$3^{\text {rd }}$ month & $10 \times 105(0-12 \times 10)$ & $7 \times 104(0-28 \times 107)$ \\
$6^{\text {th }}$ month & $11209(0-34 \times 106)$ & $166(0-10 \times 105)$ \\
$9^{\text {th }}$ month & $1478(0-9 \times 106)$ & $0(0-85 \times 104)$ \\
$12^{\text {th }}$ month & $435(0-3 \times 109)$ & $0(0-24 \times 104)$ \\
$P^{*}$ values & $0(0-10 \times 105)$ & $0(0-20 \times 104)$ \\
\hline
\end{tabular}

*Decline values of HBV DNA from 1. to 12. months were compared by using Wilcoxon signed-rank test

HBsAg seroconversion were detected only in one patient $(0.85 \%)$ at 9 th months of TDF treatment. HBeAg loss were observed in 8 (7.8\%) of the patients, $\mathrm{HBeAg}$ seroconversion were observed in 9 (8.3\%) of the patients. Data about HBsAg, and HBeAg serocoversion are given Table 3. 
Table 3. Presence and seroconversion of HBsAg, Anti-HBs Ab, HB eAg, Anti-HBe in patients under TDF, by months.

\begin{tabular}{|l|c|c|c|c|c|}
\hline & $\begin{array}{c}1 \text { st month } \\
\mathrm{N}(\%)\end{array}$ & $\begin{array}{c}3^{\text {rd }} \text { month } \\
\mathrm{N}(\%)\end{array}$ & 6 th month N (\%) & 9 th month N (\%) & $\begin{array}{c}12 \text { th mont } \\
\mathrm{N}(\%)\end{array}$ \\
\hline $\begin{array}{l}\text { HBsAg } \\
\text { seroconversion }\end{array}$ & HBsAg (+): $117(0)$ & $0(0)$ & $0(0)$ & $1(0.85)$ & $1(0.85)$ \\
$\begin{array}{l}\text { HBeAg* } \\
\begin{array}{l}\text { Positive } \\
\text { Negative } \\
\text { HBeAg lost }\end{array}\end{array}$ & $\begin{array}{l}55(49.1) \\
57(50.9)\end{array}$ & $4(3.6)$ & $6(5.4)$ & $6(5.4)$ & $8(7.1)$ \\
\hline
\end{tabular}

*Only 112 patients had HBeAg and Anti-HBeAb values.

In the means of viral response, at the sixth month of TDF treatment, complete response was found in 77 (65.8\%), partial response in 21 (18\%) and inadequate response were in 19 (16.2\%).

Among HBeAg positive patients, 44 (80 \%) patients had undetectable HBV DNA levels at the end of $12^{\text {th }}$ month and among $\mathrm{HBeAg}$ negative patients, 52 (91.2\%) patients had undetectable HBV DNA levels at the end of 12th month $(p<0.01)$.

\section{DISCUSSION}

Here, ALT normalization among CHB patients treated with TDF for 6 and 12 months were achieved by we found that among $117 \mathrm{HBV}$ patients who were treated with TDF, $12^{\text {th }}$ month ALT normalization was seen in $80.4 \%$, at the end of 6 th month $65.8 \%$ of the patients achieved complete response, only $16.2 \%$ had inadequate viral response at the end of 6 months. 96 (82.1\%) patients had undetectable HBV DNA levels at the end of 12 months. We found that none of the 117 patients under TDF treatment were "primary resistant."

The mean age of HBV positive patients under TDF treatment was $42.0 \pm 14.6$ years and 77 (65.8\%) were male. According to literature, in adult population the prevalence is higher in males and mean age differ in between 25-54 [11].

Serum alanine aminotransferase (ALT) level is an easily accessible surrogate marker for the presence or absence of disease activity of the liver and ALT normalization is used as a short-term goal for treatment $[6,7]$. In our study ALT normalization at 12th month was $80.4 \%$ in patients receiving TDF. Guzelbulut et al, Başarır et al and Demir et al. found ALT normalizations $85 \%$ vs $80 \%, 83 \%$ respectively [12-14].

The efficacy of CHB treatment is followed with ALT, HBV DNA levels, and HBe Ag status [7]. This study showed nearly $4 / 5$ of the patients achieved ALT targets and two thirds of the patients had complete viral remission under TDF. Woo et al. reported that complete remission was seen in $88 \%$ of HBV patients under TDF in European and American population. In Turkey Guzelbulut et al., and Başarır et al. found 75\% of patients had complete remission under TDF, and those studies were undertaken at the same time period of our study. The reason for the lower rate of complete remission and some patients had still high HBV DNA levels at the end of 12-month treatment in our study can be explained by the lower number of patients and inappropriate drug usage of the patients. As this was a retrospective study, we could not evaluate the drug compliance of the patients. According to first month results, all patients had $>1$ log decrease in HBV DNA levels, and we did not think about primer drug resistance. $\mathrm{HBe}$ Ag status of the patients were important in the treatment response. In other studies, TDF showed the higher effects of inducing undetectable levels of HBV DNA in HBeAg-negative patients. We found that more patients had undetectable HBV DNA levels at the end of 12 month of treatment who were HBeAg negative than HBeAg positive $(52 ; 91.2 \%$ vs. $44 ; 80 \%$, respectively, $\mathrm{p}<0.01)$. The difference in treatment response was similar the literature [13-16].

In this study, HBeAg loss was observed in 8 (7.8\%) and $\mathrm{HBeAg}$ seroconversion was observed in 9 
(8.3\%) patients under TDF. Compared to other studies HBeAg seroconversion were between 20-33\% [1316]. Only one (0.85\%) patient had HBsAg loss and seroconversion in our study $[5,15,16]$. Previous studies showed that HBsAg loss/seroconversion were between $5-8 \%$ of the patients under TDF. This difference can be explained by the small sample size, and drug compliance.

The decision to initiate treatment is primarily based upon the presence or absence of cirrhosis, the ALT level, and the HBV DNA level. The immune active phase is when a patient has an ALT level greater than the upper limit of normal in combination with a high HBV DNA level (>2000IU/mL if negative for $\mathrm{HBeAg}$ or $>20000 \mathrm{IU} / \mathrm{mL}$ if positive for $\mathrm{HBeAg}$ ), or if a patient has evidence of at least moderate liver inflammation or fibrosis. Treatment strategies for chronic HBV typically include pegylated interferon (Peg-IFN) or nucleos(t)ide analogs (e.g., entecavir and TDF) [17]. Patients with cirrhosis should be treated regardless of ALT level and at any detectable level of HBV DNA. After our study, more researches had showed the side effects of TDF in the means of renal insufficiency, renal tubular dysfunction, and decreased bone density other side effects. So that most patients were recommended TDF alafenamide, particularly in older patients and those with risk factors for renal impairment or osteoporosis [18]. Inkaya et al. aimed to determine the effects of Tumor necrosis alpha promoter polymorphisms on interferon related side effects during interferon alpha $2 b$ treatment in CHB [19]. Further studies needed to identify effects of TNF alpha promoter polymorphisms on TDF treatment in CHB.
The limitations of our study were retrospective design. As the data of the patients were collected from patients' electronic files, data about the drug compliance of the patients, or side effects under treatments cannot be evaluated. This study is not designed to compare the efficacy of TDF to other drug choices.

This study is important for showing that at the end of 12 months four to fifth of the HBV patients had undetectable HBV DNA levels under TDF treatment. Keskin et al. showed efficacy of TDF at $135 \mathrm{CHB}$ patients, our study was 117 CHB patients [20]. Our study includes high number of HBV patients under TDF in Turkey.

\section{CONQUSION}

Among patients with chronic HBV infection, TDF had satisfying antiviral efficacy. There is no primary resistance in patients treated with TDF. Patients had statistically significant improvement in AST, ALT, HBV DNA levels. Beside including the high number of TDF treated HBV patients in Turkey, HBsAg and $\mathrm{HBeAg}$ seroconversion was found to be lower than literature. Further and longer periods of researches were needed to evaluate the effects on seroconversion are needed.

\section{CONFUCT Of INTEREST STATEMENT}

The authors report no conflicts of interest. The authors alone are responsible for the content and writing of the article. 
[1] Sarin S, Kumar M, Lau G, et al. Asian-Pacific clinical practice guidelines on the management of hepatitis B: a 2015 update. Hepatology international 2016; 10(1): 1-98.

[2] Yim HJ, Lok ASF. Natural history of chronic hepatitis B virus infection: what we knew in 1981 and what we know in 2005. Hepatology 2006;43: S173-S81.

[3] McMahon BJ. Epidemiology and natural history of hepatitis B. Seminars in liver disease 2005;25(1):3-8.

[4] Kumar M, Satapathy S, Monga R, et al. A randomized controlled trial of lamivudine to treat acute hepatitis $B$. Hepatology 2007;45(1):97-01.

[5] Terrault NA, Lok AS, McMahon BJ, et al. Update on prevention, diagnosis, and treatment of chronic hepatitis B: AASLD 2018 hepatitis B guidance. Hepatology 2018;67(4):1560-99.

[6] Chen C-J, Yang H-I, Su J, et al. Risk of hepatocellular carcinoma across a biological gradient of serum hepatitis $B$ virus DNA level. Jama 2006;295(1):65-73.

[7] Lok AS, McMahon BJ. Chronic hepatitis B. Hepatology 2007;45(2):507-39.

[8] Chan HL, Fung S, Seto WK, et al. Tenofovir alafenamide versus tenofovir disoproxil fumarate for the treatment of HBeAg-positive chronic hepatitis B virus infection: a randomized, double-blind, phase 3, non-inferiority trial. The Lancet Gastroenterology \& Hepatology 2016;1(3):185-95.

[9] Keeffe EB, Zeuzem S, Koff RS, et al. Report of an international workshop: roadmap for management of patients receiving oral therapy for chronic hepatitis B. Clinical Gastroenterology and Hepatology 2007;5(8):890-7.

[10] ABIM laboratory test reference ranges. https://www.abim. org/ /media/ABIM\%20Public/Files/pdf/exam/laboratory-reference-ranges.pdf (Accessed January 2020)

[11] Tang LS, Covert E, Wilson E, et al. Chronic Hepatitis B Infection: A Review. Jama 2018;319(17):1802-13.

[12] Güzelbulut F, Ovünç A, Oetinkaya $Z$, et al. Comparison of the efficacy of entecavir and tenofoviin chronic hepatitis B. Hepato-gastroenterology 2012;59(114):477-80.

[13] Başarir I, İlikhan S, Soyaltin UE. Kronik aktif hepatit B tanılı hastalarımızın tedavi yanıtlarının değerlendirilmesi. Akademik Gastroenteroloji Dergisi 2013; 12(2):58-65.

[14] Demir NA, Kölgelier S, Demir LS. Naif Kronik Hepatit Bhastalarinin Bir Yillik 245 Mg/Gün Tenofovir Disoproksil Fumarate Tedavi Sonuçlarinin Değerlendirilmesi. Evaluation 2013; 21:25.

[15] Marcellin P, Heathcote EJ, Buti M, et al. Tenofovir disoproxil fumarate versus adefovir dipivoxil for chronic hepatitis B. The New England journal of medicine 2008;359(23):2442-55.

[16] Woo G, Tomlinson G, Nishikawa Y, et al. Tenofovir and entecavir are the most effective antiviral agents for chronic hepatitis B: a systematic review and Bayesian meta-analyses. Gastroenterology 2010;139(4):1218-1229.

[17] Terrault NA, Lok ASF, McMahon BJ, et al. Update on prevention, diagnosis, and treatment of chronic hepatitis B: AASLD 2018 hepatitis B guidance. Hepatology 2018; 67:1560

[18] Buti M, Gane E, Seto WK, et al. Tenofovir alafenamide versus tenofovir disoproxil fumarate for the treatment of patients with $\mathrm{HBeAg}$-negative chronic hepatitis B virus infection: arandomised, double-blind, phase 3, non-inferiority trial. Lancet Gastroenterol Hepatol 2016; 1:196.

[19] İnkaya A, Türk Arıbaş e, Kandemir B, et al. Role of Tumor Necrosis Factor alpha promoter polymorphisms in interferon related side effects in chronic hepatitis $B$ patients under interferon alpha 2b treatment. Acta Medica 2019; 50(2): 32 - 38.

[20] Keskin O, Ormeci AC, Baran B, et al. Efficacy of tenofovir in adefovir-experienced patients compared with treatment-naive patients with chronic hepatitis B. Antivir Ther. 2014;19(6):543-50. 